\title{
Local Governance Restructuring in Nepal: From Government to Governmentality
}

\author{
Keshav K. Acharya
}

\begin{abstract}
Local governments are the closest unit of the grassroots communities as they are not only undertaking to institutionalize the governance system and create enabling environment to promote the democratic values and public participation mainly from marginal section in decision making process, but also accelerate the economic development so that they enhance the peoples' capacity and enable them to influence the local governments representatives for responsive governance. However, Nepali society remains frustration and dissatisfaction at the citizen level, and dishonrization and dishonesty in the political and bureaucratic domain as these attributes have created the extreme risk to capacity development of the local governments. Against this perspective, the study aims to address a major research question: to what extent local governments are able to implement the constitutional granted exclusive and concurrent rights to transform the local communities, which is a consequence of governance shift from government to governmentality. Findings indicate that more capacity is required to institutionalize the restructuring process of local governance, increase citizen engagement in local governance system, build new partnerships in changing context, enhance technical, administrative, and fiscal capacity for effective service delivery, and formulate the essential laws, acts, and regulations. Nonetheless, some major arguments such effectiveness of local autonomy, political differences mainly identity based issues, productive role of outsiders, and democratization of bureaucratic assertiveness have been remained to be answered.
\end{abstract}

Keywords: capacity, local government, restructuring, service delivery, Nepal.

\section{Introduction}

Local government (LG) is a public institution in a small geographic area, such as a city, town, or county, which are the most closet and trustworthy organizations of the local citizen. Evidences indicate that such institutions have been created by national constitutions (Brazil, Denmark, France, India, Italy, Japan, Sweden), by state constitutions (Australia, the United States), by ordinary legislation of a higher level of central government(New Zealand, the United Kingdom, most countries), by provincial or state legislation (Canada, Pakistan), or by executive order (China) (Shah \& Shah, 2006). In Nepal, the provision of local government has been defined of constitution that illustrates the major duties of LGs are to deliver a range of specified services to delineated territory.In developing countries, the existence of local government is considered in a two-fold purpose. First, they are playing key roles on fund, functions, and functionaries so that they deliver the services (Mathew \& Hooja, 2009); while next is that high level of public trust fosters to involve the citizens in democratic exercise, determine public needs, and maintain accountability (Sikhakane \& Reddy, 2011). Most importantly, these institutional units operate the legislative, executive and judiciary powers over the smallest geographical areas distinguished for administrative and political purposes to equalize the national interest (Elliot \& Ali, 1988). In the local government structures, local representatives are elected by the local people in the principle of local democracy whereby they act within powers delegated or devolved to them by legislation or directives of the higher level of government. Additionally, they endow power to formulate local public policies and strategies to manage the LGs stakeholders, supervises administrative officers to establish local governance system, and exercises local government powers and functions for effective service delivery (Pandeya, 2015). Local governments in federal states comprises the third (or sometimes fourth) tier of government, whereas, in unitary states, local government usually occupies the second or third tier of government, often with greater powers than higher-level administrative divisions (Zeikate, 2002).

In Nepal, local governments were instituted during the Panchayatera in 1960, however, the design of Panchyat system was more centralized approach that put the King at the center and people in the periphery. In 1990, the democracy was reinstated and a more liberal approach was implemented in the political system that created space for local government with deconcentrated power and functions. In 2002, the tenure of the local bodies was run out and these were handed over to central government bureaucrats until 2017 to run the overall administrative and development activities at the grassroots level. Nonetheless, the bureaucrats were hardly able to deliver the local level services such as drinking water, electricity, local infrastructures, agriculture, sanitation, health, education, disaster management, and preservation of the environment (Acharya, 2016). Consequently, democratic functions and 
state efficiency were jeopardized on the one hand, on the other hand, corruption and mismanagement were rampant at the grassroots that paralyzed the local service system and downward accountability (Acharya, 2014).

In 2008, the Constituent Assembly (CA) declared the country for Federal Democratic Republic. In 2015, the federal Constitution was promulgated, which provisions three-tier governing structure incorporating the center, federal provinces, and local governments. According to the new federal constitution, there are three level of governments, namely federal, province, and local consisting of Rural and Urban Municipalities (Kelly, 2016). According to the constitutional provision, the three level of government are distinctive, independent and interrelated. Needless to say, local governments are third layer of government that is much closer to the local people. The key reasons are: First, they institutionalize a democratic and well-functioning government at the local level. Second, they are committed to deliver the public services to the local communities in an efficient, effective and responsive way. Third, they promote activities that enhance social and economic development to uplift the living standards of the ordinary people and developing organic local democratic leadership. However, the public frustration and dissatisfaction, and political/bureaucratic dishonrization and dishonesty are major attributes to create the risk of capacity for Nepali local governments (Acharya, 2014). These have led weak capacity of local government at all level in terms of providing quality service, planning, monitoring and the implementation of rule of law, proper use of financial resources, executing development interventions, and fulfilling the responsibility of both state and non-state partners.

Despite the number of reservations and arguments, the new constitution 2015 has devolved the 22 exclusive and 15 concurrent powers and responsibilities to the local governments. Similarly, the government has also restructured the local governments and determined 753 viable units. In such new local government units, the government has already completed local level election and a full board of locally elected board has been placed, and promulgated the 'Local Governance Operation and Management Act 2017'. However, the capacity of the local government to practice the constitutional power and local governance operation and management Act 2017 in the changing context of time is contentious due to the long political transition. Following the context, this study aims to cultivate capacity to restructured Nepali local governance system for effective service delivery and carry out development activities, which is the result of governance shift from government to governmentality.

\section{Local Governance: From Government to Governmentality}

Post World War II, many countries political and administration system was dysfunctional due to pathological disorders in bureaucracy; incompetency in political actors, and structural complexities in public service systemthat miscarried supply mechanism, and encouraged throat cut actions (Gildenhuys, 2004). Many authors (Richard, Grossman, \& Meissner, 2010; Hammer, 2004; Maurice, 1980) contemplate that the role of stateshould upturn to balance the economy through imposing tax, employing centralized policies, and establishing backward and forward linkages of the economy. Nonetheless, Kniivilä (2007) explain that the developing countries including industrialized societies were failed to promote the development process due to growing inequalities, and rampant corruption. In the late $1960 \mathrm{~s}$, several structural and pluralist approaches including good governance were emerged as a panacea to address the accentuated state-centrism and the power based hierarchical system (Zafarullah \& Huque, 2001). Governance is the action of governing that relates to power, and performance, equalizes government, non-government, and civil society, and responses of citizens and other stakeholders about each other's role and function(Halachmi, 2005). Thus, governing, governance and governability are obviously in continuous interaction that deals with the power structure, relationship, accountability and level of influence (Kjær, 2011). However, governance in these days evolves in distinct from of the government that acts in a way to manage power and policy, while government is an instrumental. Thus, governance is seen as an alternative to conventional top-down government control (Stoker, 1998).

To institute the art of governing system at the society including government's organs, Michel Foucault injected an idea of 'governmentality' in 20th-century through amalgamation of two concepts government and rationality. In this thesis, he analyzed both the classical liberalism and neoliberalism (Behrend, 2014). Foucault shows that before the 19th century political theory was predominantly concerned with the relationship between the ruler and the sovereign territory, seen in juridical terms, while governmental rationality has been sought at the beginning of 20th century on specific forms of knowledge that observe both the praxis of government and the nature of what is governed (Häkli, 2009). As "Foucault believes that mentality of the government is employed in a wrong orientation. First, government does not realize that they steer in a certain mindset or ideology. Second, governmentality comes from gouvernemental, which means concerning the government, and not from gouverner (to govern)" (Gertenbach, 2010, p. 11). Thus, every governments should prepare best policies and actions to fulfill the citizens' choices, and formulate citizen oriented strategies by which a society is rendered governable. In a broad term, the government regulates such type of actions under a constitution; coordinate the citizens, political leaders, and bureaucratic managers to function the power and authorities (Olsen, 2004). Nevertheless, the state appears as an instrument to steer the process of governmentality such as legislative, executive, and judicial so that it regulates the state mechanism or group of people, acts as the provider of services, emphasis power structures, and limits the freedom of choices. In this context,governmentality is an effects of rights and authorities, and progressive outcome 
of the political power of the government that emphasizes the governing of people or state in a horizontal approach (Behrend, 2014).

Cheema \& Rondinelli (2007) initiated a debate in the early 1980son the state-controlled powers and authorities that were necessarily incompetent to promote the economic and social progress of subnational units and other agents of the state. Concurrently, Przeworski (2010); Habermas (1994); and Duverger (1980) argue that the earlier period of the cold war collapsed, the numbers of government system such as dictatorship, monarchy, communism, republican and democratic were in existence and state mechanisms were running as centripetal force, which could not closely carry out the public demands. Scott (2009) further complements that the concept of government has been declined due to its delinquencies in totalizing of the rule of account and a combination of the self-regulatory process in the system.

In the Post-cold war, the approach of good governance was focused as an inbuilt system of the governing mechanism that created an opportunity to shift the governance system from government to governmentality (Enroth, 2013). Thus, governmentality analysis the mechanisms of government and its specific functional processes or practices inside and outside state institutions (Lemke, 2002). Gane (2008) adds that government is viewed not merely a sole actor but, rather, as an assemblage of diverse elements, practices, and ways of thinking coming together to both frame and resolve problems. A number of scholars (Enroth, 2013; Scott, 2009; Cheema \& Rondinelli, 2007) have argued that the shift of government towards governmentality is one of the milestones of governance to empower the people with power and authority. Cheshire (2000) refers that after the failure of the market mechanism in the late 1970s, the governmentality has been echoing in the development discourse that has encouraged pluralism such as personal responsibility, competition, efficiency and reduced assistance. Such initiatives have contributed to influencing the decision-making system and have changed the attitude and the notions of community, self-reliance and the self-help system, which are the discourses of the community service system.

Between 1974 and late 1980s, the dramatic rising of the third sectors forced the governments and the international aid agencies in many developing countries to change their roles and cooperation (Acharya, 2014). At the same time, the 'third wave democracy brought new challenges to the existing system of most developing countries in the sources of authority, their purposes to serve the people, and procedures for constituting government' (Huntington, 1991). In such condition, the emergence of the local government is a dynamic process to equalize the power and functions and succession of separate needs and demands at the bottom level. These enforce the number of countries to shift government to governmentality through local government systems.

Local governments as change agents of the society are contributing to transform the society economically, socially, and politically. The modern local governments are the parts of the libertarian trends, in spite of this, the concept has emerged in the first half of the $19^{\text {th }}$ century to support the local communities for developing their own preferences, and expressing freedom of society (Sikander, 2015). More precisely, local government is an institution, which deals microscopic interests of the locality leading to the broader concept of welfare and happiness of its people. Although local government is not a sovereign government, they act as the representative body which makes the surroundings fit to live in, keeps the streets clean, imparts education to children, build houses and paves the way to enable the inhabitants to lead a civilized life (Shah \& Shah, 2006). Abramovitz \& Eliasberg (1957) add that the evolution of modern local government system was to respond the local peoples' needs, which was produced by industrialization in the late 19th century. Due to the industrial revolution, the employment was created in bulk magnitude that encouraged pull migration and eventually urbanization took place broadly as well as service functions of the municipalities were extremely expanded (Annez \& Buckley, 2009). To end the situation, local government representatives begun to demand more power and authorities from federal governments and they raised the voice to be an autonomous institution so that they can manage and deliver the services to stipulated territory effectively.

Many authors (Bowles \& Gintis 2002; Lemos \& Agrawal, 2006) believe that the apathetic role of government, severe misuse of public funds, centralized bureaucracy, and decreasing effectiveness of the services led to quest the local governance. This concept equalizes a number of normative values, such as a network-based collaboration and coordination in the complex society; self-government; public involvement; and democratic innovation. This steered to a paradigm shift from 'government to governmentality or new governance' (O'Toole \& Burdess, 2005). Nevertheless, capacity remains the major challenge for the effective operation of the local government. Capacity is an attribute to establish the better political system, formulate strategies and evaluations that obtain through adequate knowledge, skills, and capacity of individual (knowledge, experience, skills and behaviors), organization (policies and procedures frameworks, knowledge management, and incentives), and networks (policy and strategies, power relations, and regulatory framework) (Bolger, 2000). Sanchez \& Ruiz (2008) illustrate that capacity intends to undertake the power and functions that have provisioned by the prevailing laws of the state. Increasing capacity of local governmentrequires variety of actors' support in blending the approaches, strategies and methodologies (Kauzya, 2002). However, many factors such as essential resources, social networks and collaboration, and political legitimacyinfluence the adaptive capacity of local government to respond the effective local governance (Larson, Lauber \& Kay, 2017). Although the essential resources are critically contributed to capacity development, they also seek support from intergovernmental mechanismand vertical chains to achieve the goals.

Different measures have been adopted to overcome the 
constraints and enlarge the capacity of local governments. In Australia, under the concept of 'bigger is better', council amalgamation process has been considered as historical evolution of local government (Dollery, Byrnes \& Crase, 2007). Some authors (Conway, Dollery, \& Grant, 2011) believe that local knowledge for strategic services; latest technology; outsourcing mechanism in service system; and execution of a certain amount of self-governance or autonomyare reinforcing factors of local government capacity.To increase the efficiency on service delivery, Australian government has adopted a range of strategies such as resource sharing, competitive tendering and contracting, and local government amalgamation. These have encouraged the mass participation of communities, and devolve public services from centralized government systems to a localized governing body (Dollery, Byrnes \& Crase, 2007).Despite the imperative of local government and its provision as the third tier of government, local governmentsarerealized as democratic entities in a political sphere and these entities are enjoying institutional autonomy for the efficient service delivery. In Philippines, the local governments bear major responsibilities under constitutional mandate forcapacity developmentof local elected representatives, local governmentsstaff, and local communities. The constitutional mandate has created selfconfident at the citizen level (Pratchett, 2004). In Uganda, local governments as autonomous body are answerable to local councils, in which they have facilitated to increase the extent of local participation in the policy-making process, strengthening local capacity for resource mobilization and power sharing in the provision of social services (Birungi et al., 2000).

However, many capacity development issues are yet to be resolved. For example, amalgamation into larger rural municipalities in Australia resulted in the loss of local government offices from many small rural areas (O'Toole \& Burdess, 2005). This process dismal the economic performance; failure to create social protection and social safety nets; inadequately address to institutional changes and transitional patronage politics; weak linkages and partnerships with stakeholders. Layug (2009) argues that the dismal of the Philippines local government capacity is due to the power availability, inaccessibility, unaffordability, and poor quality of public services. To overcome the situation, the government of Philippines has adopted decentralized local governance system.

In Nepal, the facts and figures of local governance at the bottom level in past was more centralized (Acharya, 2014). Numerous factors were inducing to effective implementation of decentralization policy and programmes in the past. First, institutional structure and decision making processes of the "center" itself was characterized by incapable, unorganized and weak institutional framework and decision making processes. There was no coordination between two departments under the same ministry. Second, District Coordination Committee at the district level, urban municipality at the municipality level and Village Development Committeeat the grassroots level were functioning as the local government, there organizational structure was not very much clear and accountable to the local people. Third, the institutional mechanism at local level was constituted as "council" with representation of different societal sphere was responsibility to formulate the plan and policy at the local level. However, unfair political influence made ineffectiveness of council. Similarly, a huge resources and opportunities channeled through local governments were captured by a limited group of people, leaving a large number of people out of the development mainstream. Thus, the socio-economic situations of large number of people was further deteriorated and they became dissatisfied with the establishment of the country (Acharya, 2018).

In 2015, Nepal has promulgated new constitution that envisions the concept of local governance, and three level of governments - federal, province and local. The major achievements of this constitution are to institutionalize the federal democratic republic system, end of prolonged transition; sovereignty vested on the people; improved parliamentary system; provision of advanced constitutional commissions; and economic social transformation, stability and economic prosperity. Needless to say, local governments such as rural municipalities and urban municipalities are third sphere of government which is much closer to the people. The constitution mandates to local government for 22 exclusive powers, and additional 15 concurrent powers to function at the local level. Further, the Local Level Restructuring Commission identified 753 local government units (293 urban municipalities and 460 rural municipalities) across the country. The objectives of restructured local governments are institutionalizing a democratic and well-functioning government at the local level; delivering public services to the local communities in an efficient, effective and responsive way; carry out social and economic development activities to uplift the living standards of the people; and developing organic local democratic leadership at the grassroots level. Moreover, the constitutional objectives can be figured out as fostering a mechanism to enhance the process of deepening and widening local democracy, enhancing and strengthening participatory democratic institutions, and fostering local self-governance through devolution of power.

Following the discussion, capacity of local governments is not just a matter of demanding and bargaining of power and functions, political and institutional framework, but also mean of the transforming societies from inability to ability, and incapacity to capacity. However, Nepal has just undergone the biggest socio-political change since the end of conflict in 2006, with the promulgation of its new constitution. The challenges ahead for Nepal are to institutionalize the changes that have taken place in the political landscape of the country. To end this situation, a common political consensus is apparent to fill this vacuum. Following the state, the present study attempts to identify the major gaps of the capacity development and possible best alternatives for effective service delivery at the grassroots level. 


\section{Methodology}

Currently, Nepal is divided into 77 districts, 7 Provinces, and 753 local government units for sharing of power among the governments. While conducting the study, the grounded theory approach was employed as methodology of this study, which argued to a traditional top-down theory. The grounded theory method proposes a bottom-up process of discovering "theory from data" (Glasser \& Strauss, 1967). More importantly, this method enables to collect, refine, and interoperate thedata which are collected at the field.

The fieldwork was conducted in 14 local government units purposively from 7 Provinces of the country in which 2 local governments units of each province were chosen purposively. However, the balance according to ecological region was set up during the selection process of study area. The selected local governments were: Ramasoshan Rural Municipality and Godavari Municipality (Province-7), Dolpo Buuddha Rural Municipality and Bheriganga Municipality (Province-6), Madane Rural Municipality and Tulshipur Sub-Metropolitan City (Province-5), Binaitriveni Rural Municipality and Beshishahar Municipality (Province-4), Parvatikinda Rural Municipality and Ratnanagar Municipality (Province - 3), Aurahi Rural Municipality andBardibas Municipality (Province-2), Aatharai Rural Municipality and Duhabi Municipality (Province-1). A total of 56 indepth interviews were conducted from August to October 2017 with Mayor/Chair, Deputy Mayor/Vice Chair, executive Officer, and a Dalit women member in all local government units.

Additionally, in order to triangulate the views of the local government representatives, in-depth interviews were completed with 15 national level key-informants. These were secretary and a Joint Secretary from the Ministry of Federal Affairs and Local Development, a member from Local Level Restructuring Commission, three representatives from Local Government Associations, chair of the Parliament Development Committee, 3 spokespersons of major political parties (Nepali Congress, Unified Marxist and Leninist, and Maoist Centre), 5 independent local governance experts. During the data collection period, the author physically presented,and observedlocal government capacity to practice service delivery, which were provisioned by the constitution 2015. Since the grounded theory method emphasizes the constant comparison of data with emerging categories, the theoretical categories observed in one field work in LG units were compared with categories identified in other settings.

\section{Initiatives to Bolster Restructured Nepali Local Governance}

\section{Restructuring local governance}

On $10^{\text {th }}$ March 2017, the Government of Nepal decided to implement a major territorial reform based on constitutional provision through the Local Level Restructuring Commission (LLRC). The commission recommended 753 viable local government units including 460 rural municipalities, 276 urban municipalities, 11 sub-metropolitan cities and 6 metropolitan cities at the bottom level. These local government units were further divided into 6,743 Wards. Similarly, 77 district level local governments were formed, which were 75 in the past. The creation of new local level structures is justified by the rapid urbanization process. Earlier restructured of local governance, local decision-making gave some sense of autonomy and some discretion over their affairs. In addition to the existing federal and local levels, provinces were also created with their own governing and administrative structures. Extensive tasks regarding public services was transferred consisting planning, implementation, economic development (agriculture, livestock, cooperative and industrial), social development (education, health, vital registration, social security allowances distribution, certifications/recommendation), environment, infrastructure and institutional development through new law 'Local Government Operation Act 2074'. Further, these power and functions were transferred to the Ward level structures.

In the wake of the local level restructuring, significant changes were taking place at the local levels. Amongst them, the foremost reason was the old administrative and service delivery structure was failed to reinforce the local governance effectively on the one hand. On the other hand, aim was made to develop strong local government capacity, and reduce costs by capturing economies of scale. Consequently, the old structure was replaced by the new configuration under the competencies of local governments. The enforcement of the new local units is one of the important development towards the implementation of the new constitution. However, four different issues such as size of structured local governments, public access in service functions, capacity of internal and external resources, and practice of local governance remained failing to address effective governance.

The Local Government Operation Act has provisioned to delegate many power and functions at lowest units called Wards. The Wards are regarded as the very closest units of the people, which ensure the citizens to have access of the services to the doorsteps of the people so that they have ample opportunities in services. From this way, citizen could promote the local accountability and ensuring delivery of public services. Although the elected local governments were autonomous to decide on the structure of the service delivery system, both the rural and urban municipalities were organizationally and institutionally very weak in the present context, which further supported by the unanticipated size, and geographical accessibility. This created service delivery centers of the rural and urban municipalities were remotely located as result ordinary citizens at the local level were facing hassles and problems to access the core services. This indicates bigger the size of the local governments, the lesser the possibility of accessing services easily at the local level. 


\section{Citizen engagement in local governance system}

In Nepal, the elected local government at all tires were vacated during 2001 due to insurgency war of the Communist Party-Maoist, King's apathy, power monopolization of the parliamentarian political parties, and twofold standard of the development partners. In 2006, A Comprehensive Peace Accord was materialized between Government of Nepal and Communist Party of Nepal-Maoist, afterwards an avenue was shaped for state restructuring process. On 2015, new constitution was promulgated through Constitution Assembly, the country was restructured into 7 Provinces, local government units were restructured into 753 units, and the local government election was completed in 2017. These processes were created enabling environment to engage the people in local governance process.

Past experience shows that the central government reinforced the local governance through Ward Citizen Forum and Citizen Awareness Centre. Results indicate that 31,280 local people were engaged in Ward Citizen Forums, which were constituted by bottom level local government to underpin the bottom-up approach, manage resources to implement development activities, and reach the voices of the rural communities to the local government council and then through authentic government channels to be included in the national development plans. Additionally,771,355 citizens (46\% women and $54 \%$ men) were directly engaged in community awareness center (CAC).Although this mechanism was a safeguard of the local democracy that promoted socio-economic development enterprises, created awareness on citizen rights and duties, resolved communities' disputes and social problems, facilitated income generating activities, and promoted downward accountability in the absence of elected representatives; the institutionalization of local democracy became susceptible and the voices of the voiceless were more vulnerable and deprived for basic goods.

In Nepal, the local level election was held in 2017 after declaration of the new constitution that endowed a large section of population, especially youth were participated in local democratizing practices for the first time to establish the cooperative, collaborative, and coordinative federalism. This election allowed power and resources to the local level and gave people a stronger voice in how their communities are governed. The last time election was held in 1997 during the course many youths were left in the electing process of local representatives. However, the local level election 2017 endowed the opportunities to the people after 15 years to elect the representatives. Although some Madhesi political parties opposed the government's decision to hold the election without amending the constitution, the great support of the largest mass of the population and continues assistance of the development stakeholders' the government completed the phase wise local election.

In the wake of successful three rounds of elections, a total of one crore 40 lakhs 54 thousands and 482 people were directly engaged. Through their votes, 36,639 people's representatives including chairperson, vice chairperson, ward chairperson and council members were elected for 753 local levels. Based on the provisions of constitution, local governments initiated to practice legislative judiciary and executive functions at the local level. In addition, they established 9-member District Coordination Committees to coordinate between the center, province and grass root level governments. The local election gave an end to nearly two-decade long vacuum in local governments in which they were led and managed by the central government. The government of Nepal from this fiscal year started allocating budget directly to local governments under two headings viz., equalization grants and conditional grants based on the provisions for revenue sharing outlined in the new constitution. The money allocated to local governments was transferred to their accounts. It was Nepal's first experience of local governments having the mandate to autonomously choose their priorities and spent resources at their proposal.

Despite such foremost efforts of the government, Nepal's local governance was criticized for a number of matters such as conventional service delivery system; accountability deficit; excessive political interference; bureaucratic apathy, and elite osteopathy. These enforced citizens for meaningless participation and too little engagement of the people from marginal section of the communities. The local people assumed that local government was associated with their day to day life as they believed federal government assigned staff was not in the position to lead the local government and address their' voices. Similarly, local communities get access to the local government institutions in the absence of their representatives became hard to reach. However, the creation of strong local government institutions through constitutional arrangements could redress the gaps and deficits of a liberal democratic polity by promoting the participation of the people in the democratic process, rejuvenating and enlivening the democratic institutions at the local level.

\section{Building new partnerships in new context}

Development partners have been engaged in various development activities as partner of the government for more than 60 years in Nepal. These support reinforced the local government mainly on infrastructure, capacity development, good/fiscal governance, institutional development, planning and policy feedback, while they built patron-client relationship and created dependency syndrome at the government and public level. Thus, both government and public institutions were reluctance to generate and mobilize own internal resources that contributed the role of development partners' imperative. Although the roles of development partners were positive in managing political transition, their connection with many instance directly tied to the elite group produced misunderstanding. For example, ethnic movement, MadheshiandTharu movement, and other identity based movements were directly and indirectly supported by the 
development partners caused transition was unnecessarily enlarged in the country.

Nevertheless, development partners' support to the government was still persistent to carry over the local governance, and community mobilization. In addition, government was conducting capacity development training to Chief Administrative Officers, local government heads and deputy heads on Local Government Operation Act 2017 and other relevant issues on the support of development partners. Concurrently, some other development partners supported the local government individually in capacity development initiatives such as preparing Revenue Improvement Action Plan, Integrated Property Tax, developing information materials, and integrated sector development plan. Furthermore, development partners were working closely with government and stakeholders to support Nepal in fulfilling the common commitments to Agenda 2030, and its localization initiatives to achieve the sustainable development goals. Recently, the central government was attempted to design a Sub National Governance Program aiming to improve public services at the local level through a combination of strengthened local governance and the promotion of innovative service delivery approaches. The project has been designed with number development partners under different financing arrangements to strengthen devolution and improved local governance system for the effective delivery of services and the empowerment of citizens, especially women, children and disadvantaged groups. This significant initiative aimed to bring the government closer to the people and empower the citizens to hold their elected governments accountable for the use of political authority, carried out development activities, and generated financial and natural resources.

Nonetheless, there were still some shortcomings such as the continuance of hierarchical power structures, which limited the power and rights of the people in expressing their grievances and opinion. In the local government units, there were unknowingly unfair competition was growing up among the central government, local government and development partners. As the federal government intended to maintain the local governments as line department of the central ministry based on inter fiscal resource transfer, while local government assumed they were independent units based on constitution. For the development partners, they intended to support the local government rather federal and provincial government because they wishedfor creating dependency syndrome at the local level. However, the mission to strengthen federalization process could not be achieved unless and until to remove the powerbased hierarchical system, patron-client relationship, and resources paucity.

\section{Technical and administrative capacity for effective service delivery}

The constitution 2015 considers that the local governments are major domain of government at the bottom level, constituted based on principal of subsidiarity. Post 2002, the local government units were largely steered by the centralized mechanism, which failed to reach the services to the doorstep of the local people as result people were obliged to travel either district headquarter or capital city Kathmandu for each and every thing. To end the public constraints, the Constitution 2015 has conferred extensive roles, powers and responsibilities on local units to develop their area by themselves. Earlier, the service functions of the local bodies were approved by the National Planning Commission and directed by the concerned ministries for execution. The budget allocation process of local government was completed after completing 14 steps of participatory planning process. Now, local governments themselves are responsible to formulate and approval the plans, promulgate laws on health, education facilities, infrastructure development and fiscal resources. They can project their sources of revenue, claim the resources with provincial and federal governments, allocate the resources, prioritizes the program.

Despite the fact, the institutional arrangements of the local government in Nepal were deeply flawed. There was huge gap in terms of knowledge, skills, and power structure between central government and local government staff. The central government staff by virtue they enjoyed with state power and resources while local government staff involved as merely supportive staff were demoralized by the central government staff. The LG staffs were depressed as they were recruited on the basis of nepotism, and favoritism in which their contract paper was prepared in a sheet of the cigarette box. This type of power structure neither LG staffs' confidence level was scaled up nor capacity was transformed to the local government level. As result local employees were indicated as passive service providers and unsuccessful to facilitate the democratic and inclusive development.

Nevertheless, the continuous efforts of both government and non-government partners in the past decades to enhance the capacity of the local employees helped the employees to improve work capabilities, faster team work, effective decision-making. In addition, government focused the capacity development agenda at the local government was a primary agenda to adjust the employees, operate the exclusive and concurrent power, execution of intergovernmental fiscal framework; maintain public financial management, and accountability for improved infrastructure and services. To end these, the parliament approved Employees Adjustment Act (2074 B.S.) as per their functions and mandates outlined in the constitution. The key objective of the Act is to reorganize the existing unitary structure of civil service so that government can re-allocate, adjust, and transfer the civil servants under public services into the federal, provincial and local levels. To function the federalization competently, government revealed that 90,000 employees will be needed to function the federalization from bottom to top level of the government. However, 87000 civil servants currently employed in the different ministries, departments, districts and grassroots level, and 17102 staff were engaged in the local government units. The preliminary estimation shows that local governments need 50000 employees, while 
provincial and federal governments require 15000 and 25000 respectively.

However, organization and management including HRD plans, and capacity need assessment are needed to focus through training, study tours, workshops and such kind of exposures. Similarly, the poorly staffed local government administration further lacks employees with technical competence on some essential fields mainly on engineering, finance, legal, and information technology were created biggest disappointment at the local level.

\section{Fiscal capacity to lead the local governance}

The constitution of Nepal provisions the exclusive and concurrent power and functions for different level of governments in different schedules. As per constitution, local governments usually generated only about onethird of their financial resources through taxation and fees for services. Their principal financial source was the fiscal transfers from the federal government which was estimated to make up about two-third of their total income. Recently, the government approved the InterGovernmental Fiscal Transfer Act (2074 B.S.) to regulate revenue powers, revenue allocation, grants, borrowing, budget management, public expenditure and financial discipline at all level (federal, provincial and local levels). The Act is a crucial legislation which provides legal basis to distribute revenue among different levels of government in a fair and equitable manner. On the basis of this Act, different levels of governments could collect taxes and non-tax revenues. Federal government transfers to local governments in four major types: Fiscal Equalization Grants, Conditional Grants, Complementary (Matching) Grants, and Special Grants.

In addition, the Inter-Governmental Fiscal Transfer Act have proposed 15 different types of taxes and fees to enable them to cover various recurrent and capital expenses such as house rent, real-estate registration, vehicle, land, entertainment, advertisement, business and hoarding board taxes. They were also allowed to collect fees from various types of services, tourism, collection of herbs and scrap, and operation of carts, rickshaw, cable cars and boats. These initiatives empowered the local governments to institutionalize federalism at the local level. As per this provision, local bodies will get 15 percent of the income generated from VAT, and excise duties imposed on domestic products.

The local levels were to use nearly 18 percent of the total annual budget of the country in FY 2016/017. Of NRs.1278.99 billion annual budget was allocated for the coming Fiscal Year 2017/2018, the local level received NRs. 225.05 billion or 17.6 percent of the total budget. Of which, NRs. 148.63 billion was allocated as equalization grant and NRs. 76.41 billion as conditional grant. As per the budget allocation, rural municipalities received minimum of NRs. 100 million and maximum of NRs. 390 million, municipalities received minimum of NRs. 150 million and maximum of NRs. 430 million, submetropolitan cities received minimum of NRs. 400 million and maximum of NRs. 630 million and metropolitan cities minimum of NRs. 560 million and maximum NRs. 1.24 billion as per the grant allocation. Similarly, the sectoral ministries' supporting projects and programs with budget up to NRs. 5 million for rural municipality, up to NRs. 10 million for municipalities, and up to NRs. 20 million in sub-metropolitan and metropolitan cities.

Current practice of federalization and devolution enforced to allocate a huge budget to the local levels on the basis of size of administrative area (15 percent), size of population (70 percent), human development index (5 percent) and under development indicator (10 percent) on the one hand. On the other hand, they had more responsibilities including education, health, infrastructure development programs, waste management, water supply and sanitation program, local transportation, small irrigation, and many more. Given a new situation and huge chunk of budget, rights and responsibilities, it was highly needed that the functionaries of the local government are imparted with capacity development training so that they perform their duties efficiently.

However, criticism remained to successful accomplishment of the fiscal federalism due to various reasons. First, many LGs they did not have revenue improvement action plan due to lack knowledge of its principle that created dependency on federal and provincial government grants, LGs were failed to make sufficient use of their taxation powers. Second, effective administration of assigned revenue sources requires an appropriate institutional set up with necessary laws and guidelines, and mechanisms for their implementation, innovative technology, skilled human resources, and performance management and accountability framework. However, institutional capacity in the local governments found severely weak. Third, insufficient clarity found on expenditure and revenue assignments of each level of government, which is critical for a sound fiscal federal system. Number of revenue sources is either common across different government tier and/or were listed in the concurrent schedules. Finally, some local governments have begun imposing taxes, fee and royalty on institutions and projects within their geographical jurisdiction that created unhealthy tax competition and inefficient movement of capital and resources. One local government unit in the study area, for example, demanded annual royalty of one million rupees from a hydropower project operating with territory of the local government. Others have raised property tax, tourism tax, local resource utilization tax and so on. These arbitrary decisions impact overall investment climate and economic growth.

\section{Formulation of laws, Acts and regulations}

Post enactment of the Local Level Restructuring Commission report, the government prepared an executive order 2073 (B.S.) to manage the jeopardized situation of newly restructured local governments, which were headed by the central government staff. Soon after, the government completed the phase wise local election. Although the 
government tabled the Local Government Operation Bill to the Parliament couple of months before, some reservations remained to the Communist Party-Maoist and Nepali Congress, the Bill was forwarded to the Parliament Development Committee for further discussion. Despite the political differences, the government forwarded the local level Executive Order, 2074 to expedite the services to be provided by the local governments. Nevertheless, the elected representatives believed that 'Executive Order 2074" were cut down their rights.

On 15th October 2018, the Parliament Development Committee endorsed the Local Government Operation Act -2074 (B.S.) to implement the provisions related to the powers of the local level as per the constitution. In order to promote cooperativeness, co-existence and coordination between the federation, province and local level, and deliver efficient and quality services by ensuring people's participation, accountability and transparency, and institutionalize the legislative, executive and judicial practice at the local level, the Local Governance Act has foreseen main significant points. It defines the structure and basis of different types of local governments, prescribes the procedures for the local governments to merge (with one another) and also to change their centers and boundaries on the basis of local needs, provides detail of the functions of local governments, different authorities of local governments (e.g. Mayor, Deputy Mayor, Ward Chairpersons, Chief of Administration, etc.), defines the procedures of local governments (such as Assembly and operation), provides instructions and basis for annual planning and budgeting, and prescribes administrative structure and provision of staff. Similarly, it envisages the powers have devolved to the Ward levels from rural and urban municipal centers in different functions mainly formulation, implementation and monitoring of plan; data updating and preserving; development work; regulative functions; and recommendation and certification. Although the Local Government Operation Act has been described as revolutionary and is considered to have laid foundation for autonomous local governments under new federal structure, the Act has also been criticized in different points. First, it allows local governments to limit sources of revenue which is insufficient when compared to the list of functions local governments are supposed to perform. Second it does not address the capacity gaps among elected representatives and administrative staff. Third, some functions, which were unbundled by the central government were not clear and sufficient. Finally, central control has been maintained through the leadership of centrally delegated Chief Administrative Officer as the head of administration.

In addition, the constitution and Local Government Operation Act granted authority to local governments to formulate and authenticate the laws through their assembly. However, the local government should be careful such formulated local laws would not contravene with the federal and provincial laws. During the course, local governments can formulate the laws for local affairs including formulating laws, tax collection, local legislation, policy-making, social security, development planning, administration, and disbursement of benefits and local development funds among other several affairs. Based on these realities, federal government formulated 30 kinds of 'model laws' to facilitate the local government aimed at following uniformity. These comprise local government execution regulations, work division regulations, laws regarding to authenticate the decision and order, model code of conduct, rural and urban assembly operation regulations, laws regarding to legislature procedure and laws regarding the local taxation among others. Furthermore, various model laws were made with the aim to help operate the local levels on the basis of the level power as per the Schedule - 8 of the constitution. Additionally, some more laws needed to prepare at local level. However, the capacity, knowledge, and law enforcement mechanism at the local government considered very weak. At the local government, the absence of human resources concerning legal background as well as knowledge and experience of local governance, and lack knowledge about the local government about the important of legal framework, effective service delivery was inclined.

\section{Discussions: From Government to Governmentality}

\section{Local autonomy: prospect or status quo}

Nepal has formally devolved legislative, executive and judicial power to the local government through constitution. The provision of exclusive and concurrent rights of local governments is a major shift from 'government' to 'governance' and transformation from hierarchic to more network system. These shifting power structure have created prospects of transforming local governance, offered the services to the grassroots people at their doorsteps, and equalized the power relations at the various level of the governments. In addition, the completion of the local level election, and promulgation of the Local Government Operation Act have instituted the democratic values, and encourage to enact fund and functions at the local governments. The functions are ranged plan formulation and implementation, judicial works, financial jurisdictions, and administrative structure. Additionally, local governments can coordinate to users, private sector, community organizations, cooperatives and non-government organizations to bring synergy effect in development. Following the context, orientation programme on 'Operation of Local Government and Budget Formulation' for the local level representatives by the federal government was a key approach to capacitate the local government representatives in the planning, budget formulation and endorsement, good governance and code of conduct of the elected local representatives, revenue collection and taxation.

However, the current situation at the local level units remained several confusions, which have forced muddling local governance. The functions of local governments were in a very nascent stage and could not work well due 
to lack technical capacity of political and administrative staff, unavailability of administrative building to human resource, poor compliance of directives of elected representatives, deficit knowledge and skills to promulgate local laws, and sluggish implementation of annual program and budget. Similarly, elected local leaderships also have differences in understanding on several affairs. They consider that the formulation of laws and arrangement of human resources and budget are the responsibilities of the center and their roles are to implement them. In Addition, the local autonomy is influenced by hierarchical relations as local governments are considering as regulating agency of the federal government.

\section{Endless differences: concluded or hibernated}

On 20th September 2015, Nepal promulgated the new constitution through Constituent Assembly, which was endorsed by 90 percent of the total legislators. The Nepali people exceptsome politically oriented Madheshiwelcomed the constitution and celebrated by organizing different events nationwide. The people also expressed hope for a better future as they realized the country has entered into an era of stability. Much of the international community apart from India welcomed the new constitution. The major important aspects of the constitution are restructuring Nepal into a federal republic system with 77 districts, 7 provinces, and 753 local governments. Similarly, a bicameral parliamentary system has been created with two federal houses and unicameral parliamentary systems in each province. Another significant step of the constitution is to ensure the rights of disadvantaged communities and bring them into the mainstream of development.

Despite the adequate provisions of rights for the communities, there are concerns that the benefits only reach to the leader rather local people. Similarly, the state restructuring process in Nepal was very chaotic, which was not based on capability approach. This led Madheshi political parties largely opposed to the restructuring process, particularly the new federal boundaries, as they believe that the current constitution could not dig the way out of Madheshis' suppressions. Since walking out of the process, the Madheshi political parties were organized protests opposing the agreement, forming an alliance called the United Democratic Madhesi Front, which protested to call for nationwide strike against the constitution including blockade of India Nepal Boarder. The United Democratic Madhesi Front's major demands included the implementation of all past agreements reached between the United Democratic Madhesi Front and the government, two provinces to be part of the entire Madheshbelt, an electoral constituency based on population only, an amendment to citizenship laws, and proportional representation in every state institution.

However, it was hard to understand the logic of the agendas raised by United Democratic Madhesi Front. The opposition pointed out that the United Democratic Madhesi Front was mobilized by the India as they put such agenda on Indian interest. Initially, the disagreement was originated from a 7-point agendas, later that extended up to 35-poinst. Although Communist Party Unified Marxist and Leninist led collision government registered the agendas as amendment bill in parliament, the United Democratic Madhesi Front remained dissatisfied, saying that all demands must be met before they will come to the negotiation table. Soon after the collision government was dismissed and Nepali Congress lead collision government was formed with support of United Democratic Madhesi Front. The new government registered the agenda of major constitutional revision as amendment bill in parliament. However, the Unified Marxist and Leninist including some other small political parties had reservation to major revision of constitution on the demand of United Democratic Madhesi Front. On 21st August 2017, the constitution amendment bill was failed through Parliament that enforced United Democratic Madhesi Front to mainstream in the political discourse as result they were participated in the third phase local election in Province 2 and other federal and provincial elections. Nonetheless, the United Democratic Madhesi Front have been sparked the political agenda, while country has been focusing the economic prosperity.

\section{Role of outsiders: Enabler or inhibiter}

In order to institutionalize the federalism and local governance, various institutions such as development partners (DPs), bilateral organizations, private sectors and individuals have been involved according to their interests. Their main contribution endured with financial support in project activities, capacity development, and infrastructure development, all of them were considered as outsiders. In Nepal, development partners spent over NRs 89 billion since the fiscal year 2016/017 for various constitutional organs and government ministries, including national security. According to the statement of technical and other assistance published by the Ministry of Finance, the DPs spent NRs 88.98 billion that indicates government's dependency on DPs within the ministries have been increasing in corresponding years.

Although the government had taken a decision not to accept any conditional assistance from DPs, the decision was revoked and failed to comply in government organs. Some of the high level bureaucrats argue that DPs should be kept away from the country's policy-making bodies, including the prime minister's office, parliament, the Supreme Court, ministries dealing with security, the president's office and the offices of the speaker and the chief justice. However, such approach eventually failed due to pressure from various angles including the political leadership. Currently, 179 DPs are supporting for 134 projects mainly for capacity development trainings, income generating activities, accountability, few infrastructure development, amounting to NRs 88.98 billion under 18 ministries. According to the Finance Ministry, the projects will run till December, 2018 that indicates not only the greater dependency of Nepal on development funds but also has created imbalance of economic development, 
and set up the client-patronage systems, although donors appear vociferous against corruption and instability in political and administration system and malfunctioning of governance, and effective to operate of the federalization and redouble improvement of the local governance.

Similarly, New Delhi and Beijing are especially concerned about the Nepalese federalism process and election result as both Asian giants are competing to increase their influence in the Himalayan nation. Although India and Nepal has similar geographical locations and accessibilities, economic inter-dependency, religious and cultural similarities that caused people of Nepal have more empathy to the India. However, India exerts a greater influence on Nepali politics that imposed an economic blockade soon after the promulgation of constitution to support the Madheshi political parties. As India argued that the economic blockade on Nepal was created security threat caused by the protesters of Madheshi. On the other hand, Chinese support through Presidential speech in the 70th session of the UN general assembly that the big, strong and rich should not bully the small, weak and poor, the principle of sovereignty not only means that the sovereignty and territorial integrity of all countries are inviolable and their internal affairs are not subjected to interference. Both helpful and unhelpful intents have created mystification to institutionalize the federalism and equalize the power intelligently.

\section{Bureaucracy: Accelerator or Controller}

The bureaucratic apparatus in Nepal is being modernized and empowered to enhance the process of socio-economic development and undertook massive development activities. Although the role of bureaucracy was satisfactory during the absence of political representatives at the local level, bureaucracy overwhelmingly powerful but less enthuse to maintain the local governance, accountability, and integrity. This situation was usually prevalent all tiers of local bodies in Nepal. The constitution of Nepal, 2015 embraces federalism as one of the salient features, also envisages socialism besides eternal peace, prosperity and development. However, the current practice of administrative readjustment indicates that Nepal's bureaucracy viewed as antagonist to the government. It stood unhelpful in institutionalizing local democracy and local governance.

Although the role of Nepalese bureaucracy in the past was highly honored for its managerial skills and devotion, the commitment of the bureaucracy in the aspects of governance such as devolution of powers and service delivery functions, and equalize power structure with political managers in formulating public policies was highly appreciable. Post promulgation of constitution, an approach of power devolution from center to local level was widely instituted. During the local election a popular slogan "GAUN GAUN MA SINGH DURBAR" (major power functions in each local government) was sparked by the Major political parties as they explained that the past local election was held in 1996 in which the power and functions were merely delegated, and government was failed to shift the power from Singha Durbar to the grassroots. However, this time local level is much stronger on the basis of constitutional provision as they have enriched by all level of powers legislative, executive and, judicial.

Currently, the government was on pressure to manage the existing structure of the civil service as per the newly restructured public sector. A total of 87,000 civil servants are said to have been employed by the then-central government, many of whom need to get transferred, or deployed at the state and local governments. However the role of bureaucracy to institutionalize the new practice of the federalization is crucial. Part of the problem was the unnecessary demand of trade unions for automatic one-step promotion, and increment of salary and other facilities. Nepali bureaucracy is working at the center performs as a strategic core especially at the policy level while those serving at the provinces and local governments will have to focus on implementation and service delivery. Similarly, the adjusted bureaucratic staffs were reluctant to move to provincial and local levels on the one hand due to remoteness of duty stations, lack of opportunities for further career growth and technological gaps. On the other hand, Nepal's bureaucracy was one of the exclusive, weakest and poor performing entities because of many layers in the decision-making process, centralist and self-centric mindset, and less motivated. The key reasons were rent seeking behaviors, power and position-oriented culture, unquestioned loyalty to political masters and linkages to parties. Consequently, they failed to build confidence to deliver the goods and services to the citizens.

\section{Conclusion}

Local governance is a unique system whereby various actors can come together, discuss about the local issues, elect their representatives, and take decisions on their behalf. Vibrant local governments are an imperative part of well-governing system as they are very closest units of the people, which ensure the citizens to have access of the services to their doorsteps. Additionally, they encourage people to take a stake of governing system, and create conducive environment for reconciling conflicts. In this process, they were restructured by size, shape and functions. Recently, these units were fulfilled by democratizing practices of local election, which ended to nearly two-decade long vacuum in local governments in which they were led by the central government. This process created an enabling environment to engage more than 40 lakhs people in the political decision making process and allowed of power and resources to the local level. Although some Madhesi political parties opposed the government's decision to hold the election without amending the constitution, the great support of the largest mass of the population and continues assistance of the development partners' the government completed the phase wise local election.

Post-election, local government units were enriched 
by legal instruments such as local government operation Act and number of other Acts. These efforts have enhanced the capacity of both local representatives and employees in improving capabilities, faster team work, increasing job satisfaction, and improving decision-making. In addition, the government has focused on the capacity development of elected officials, adjustment of the employees, implementation of exclusive and concurrent rights, execution of inter-governmental fiscal framework; and implement the infrastructure development as primary functions. To end these, the government approved Employees Adjustment Act as per the major function outlined in the constitution. To functionalize the federalism competently, government revealed that 90,000 employees will be needed to functionalize the federalization from bottom to top level of the government. However, 87,000 civil servants have currently been employed in the different ministries, departments, districts and grassroots level, and 17,102 staffs were engaged in the local government units.

To manage the current practice of federalization and devolution, a huge volume of budget to the local levels on the basis of size of administrative area, size of population, and a poverty indicator is required to accomplish the services. Additionally, formulation of laws and regulations including tax collection, local legislation, social security, development planning, administration, work division regulations, among other several affairs are needed to be formulated. However, figures indicate that only 18 percent of the total annual budget of the country in FY 2016/017 was used by the local levels and less than 10 Acts and regulations have been formulated at the local level. The key reasons were the absence of human resources concerning theme based technical background as well as knowledge and experience of local governance.

\section{References}

Abramovitz, M. \& Eliasberg, V.F., (1957). Government in Nineteenth Century Great Britain. In M. Abramovitz \& V. F. Eliasberg (Eds). The Growth of Public Employment in Great Britain. London. Princeton University Press.

Acharya, K.K (2018). The capacity of local governments in Nepal: from government to governance and governability? Asia Pacific Journal of Public Administration.40(3), 186-197.

Acharya, K. K., (2016). Impaired Governance: Limiting Communities' Access to Service Delivery System in Nepal. Himalayan Journal of Sociology and Anthropology. Vol. 7, 40-74.

Acharya, K. K. (2016). Community Governance: An Emerging Archetype Shift Insurgency towards Peacebuilding in Nepal. In P. Adhikari, S. Ghimire, \& V. Mallik (Eds.), Transition to Peace: A decade of the comprehensive peace accord 2006-2016 (pp. 433456). Kathmandu. Nepal Transition to Peace Institute (NTTP-I).

Acharya, K. K. (2014). Relevance of Community Governance for Basic Service Delivery in Nepal: An
Empirical Study. (Unpublished doctoral dissertation). University of New England, Armadale, NSW, Australia. Annez, P.C. \& Buckley, R. M., (2009). Urbanization and Growth: Setting Context. In M. Spence \& P.C. Aneez (Eds). Urbanization and Growth (pp. 1-47). Washington D. C., The World Bank.

Behrend, B., (2014). The Supranational Governmentality of Neoliberalism: An Analysis of the Governing Principles of Troika Programs for Greece, Politikon: IAPSS Political Science Journal, 26, 33-47.

Birungi, H., Kwagala, B., Muwanga, N., Onweng, T. \& Trondsen, E. J., (2000). What Makes Markets Tick? Local Governance and Service Delivery in Uganda, Asian Review of Public Administration, 11(1), 26-49.

Bolger, J., (2000). Capacity Development. CIDA Occasional Series. 1(1): 1-8.

Bowles, S., \& Gintis, H. (2002). Social capital and community governance. The Economic Journal, 112(483), 419-436.

Cheema, G.S. \& Rondinelli, D.A., (2007). From Government Decentralization to Decentralized Governance (In Eds.) G. S. Cheema \& D.A. Rondinelli. Decentralizing Governance: Emerging Concepts and Practices. (pp.1-20). Washington D.C., Brooking Institution Press.

Cheshire, L. (2000). Contemporary strategies for rural community development in Australia: A governmentality perspective. Journal of Rural Studies, 16, 203-215.

Conway, M. L., Dollery, B. \& Grant, B., (2011). Shared Service Models in Australian Local Government: the fragmentation of the New England Strategic Alliance 5 years on. Australian Geographer, 42:2, 207-223

Dollery, B. , Byrnes, J. \&Crase, L. (2007). Is Bigger Better? Local Government Amalgamation and the South Australian Rising to the Challenge Inquiry. Economic Analysis and Policy. 37(1): 1-14

Eade, D (1997). Capacity-Building: An Approach to People-centered Development Oxfam Publication, London.

Elliot, J. \& Ali, S. (1988). The State and Local Government Political Dictionary. North Carolina. Borgo Press.

Enroth, H., (2013). Governance: The art of governing after governmentality. European Journal of Social Theory. 17(1): pp. 60-76.

Gane, M. (2008). Foucault on Governmentality and Liberalism. Theory, Culture, and Society. 25(7-8): 353363.

Gertenbach, Lars (2010): Die Kultivierung des Marktes: Foucault und die Gouvernementalität des Neoliberalismus, 3rd (eds). Berlin: Parodos Verlag.

Gildenhuys, J. S. H. (2004). Ethics and Professionalism: The Battle Against Public Corruption. Stellenbosch, Sun Press.

Hakli, J., (2009). Governmentality, (In Eds.) Kitchin, Rob \& Thrift, Nigel. International Encyclopedia of Human Geography(pp. 628-633), Vol. 4. Oxford: Elsevier.

Halachmi, A. (2005). Governance and risk management: challenges and public productivity. International 
Journal of Public Sector Management, 18(4), 300-317.

Habermas, J., (1994). Three Normative Models of Democracy. Constellations. 1(1): 1-10.

Huntington, S. P. (1991). The third wave: Democratization in the late twentieth century. New York. University of Oklahoma Press.

Kauzya, J. M. (2002). Local Governance Capacity Building for Full Range Participation: Concepts, Frameworks, and Experiences in African Countries, 4th Global Forum on Re-Inventing Government, New York, United Nations, pp. 361-362.

Kjær, A. M. (2011). Rhodes' Contribution to Governance Theory: Praise, Criticism and The Future Governance Debate. Public Administration, 89(1), 101-113.

Kelly, R. (2016). Stock-taking of Fiscal Decentralization Policy in Nepal. Journal of Fiscal Federalism. 1(1): $1: 16$.

Kniivilä, M. (2007). Industrial development and economic growth: Implications for poverty reduction and income inequality. Industrial Development for the $21 \mathrm{st}$ Century: Sustainable Development Perspectives. New York, United Nations.

Layug, A. (2009). Triangulation framework for local service delivery, PIDS Discussion Paper Series. Makati City.Philippine Institute for Development Studies.

Larson, L. R., Lauber, T. B., \& Kay, D. L. (2017). Local government capacity to respond to environmental change: Insights from towns in New York State. Environmental Management, 60(1), 118-135.

Lemke, T., (2002). Foucault, Governmentality, and Critique. Rethinking Marxism, 14 (3), 49-64.

Lemos, M., \& Agrawal, A. (2006). Environmental governance. Annual Review of Environment and Resources, 31(1), 297

Mathew, G. \& Hooja, R., (2009). Republic of India. In Nico Steytler (Eds.) Local Government and Metropolitan Regions in Federal System. (pp.166-199). Quebec. McGill-Queen's University Press.

Maurice, D., (1980). A New Political System Model: Semi-Presidential Government. European Journal of Political Research. 8: 165-187.

Olsen, J. P., (2004). Citizens, public administration and the search for theoretical foundations. PS Political Science \& Politics, 37(1): 69-79.

O'Toole, K., \& Burdess, N. (2005). Governance at community level: Small towns in rural Victoria. Australian Journal of Political Science, 40(2), 239-254.

Pandeya, G.P. (2015). Does Citizen Participation in Local Government Decision-Making Contribute to Strengthening Local Planning and Accountability Systems? An Empirical Assessment of Stakeholders' Perceptions in Nepal. International Public Management Review. 16(1): 67-98.

Pratchett, L. (2004). Local Autonomy, Local Democracy and the 'New Localism', Political Studies. 52(2), 358375.

Przeworski, A. (2010). Democracy and the Limits of SelfGovernment. New York. Cambridge University Press.

Richard S. Grossman, R.S. \& Meissner, C.M., (2010).
International aspects of the Great Depression and the crisis of 2007: similarities, differences, and lessons. Oxford Review of Economic Policy, 26(3): 318-338.

Rondinelli, D.A. (1981). Government Decentralization in Comparative Perspective in Developing Countries, International Review of Administrative Sciences, 47(2): 133-145.

Sanchez, V. A. \& Ruiz, M. (2008). Competence-Based Learning, Bilbao. University of Deusto,

Scott, James C. 2009. The Art of Not Being Governed: An anarchist history of upland South East Asia. Connecticut. Yale University Press.

Shah, A. \& Shah, S., (2006). The New Vision of Local Governance and the Evolving Roles of Local Governments. In Anwar Shah (Eds.) Local Governance in Developing Countries (pp 1-44). Washington, D.C.: The World Bank.

Sikander, T. (2015). A Theoretical Framework of Local Government. International Journal of Humanities and Social Science. 5(6-1). 171-176.

Sikhakane, B.H. \& Reddy, P.S., (2011). Public Accountability at the Local Government Sphere in South Africa. African Journal of Public Affairs. 4(1): 85-102.

Stoker, G. (1998). Governance as theory: five propositions. International social science journal, 50(155), 17-28.

Zafarullah, H., \& Huque, A. (2001). Public Management for Good Governance: Reforms, Regimes, and Reality in Bangladesh. International Journal of Public Administration, 24(12), 1379-1403.

Zeikate, S. (2002). Investment Transfers: Survey of Ten Developed Countries. The Washington D.C., The World Bank.

Acharya, Keshav K. Phd is a researcher of University of New England and works at Capacity Development of New Municipalities, German Development Corporation, Kathmandu, Nepal. His main interest areas are governance, service delivery, and community development. He holds MSc in Rural and Regional Development Planning from the Asian Institute of Technology Thailand. Dr. Acharya as a development practitioner worked in different positions and projects of UNDP and other development projects (Nepal, Thailand, and Australia) for more than 15 years. Additionally, he persuaded number of research and development projects in the area of capacity gap assessment of central and local government bodies, impact assessment of community development, and formulation of local government strategic plans and disaster plans. He has written some books, articles and research papers, which are published in peer-reviewed international journals and book chapters.

Email: keshavkacharya@gmail.com 